\title{
Early-onset scoliosis: a comprehensive guide from the Oxford meetings
}

\author{
Colin Nnadi: Thieme Verlag, New York, Stuttgart, Delhi, Rio, 2015, 158 pp, 210 Illustr., \\ Hardcover, Listprice: EUR (D) 139.99, EUR (A) 144.00, CHF 196.00, \\ ISBN: 978-3-13-172661-2
}

\author{
Pierre Kehr ${ }^{1}$
}

Received: 12 April 2016/Accepted: 25 April 2016/Published online: 30 June 2016

(C) Springer-Verlag France 2016

This book is the summary of an Oxford meeting held in 2011 gathering the cream of the specialists in children spine deformity. This book is like a bible in this area: complete, written very small and a little boring. But everybody concerned by the subject will find an answer to all his questions about this painful problem. All the aspects of growing spine and deformity are treated and the members of faculty share their experience to conclude that early-onset scoliosis still remains a complex situation where medicine can progress. As said in the preface by Colin Nnadi, it is hoped that by reading the book, the individual develops a better understanding of what earlyonset scoliosis is and focuses not on specific treatments but on principles to inform choice on best treatment.

Compliance with ethical standards

Conflict of interest None.

Pierre Kehr

pierre.kehr@gmail.com

1 Strasbourg, France 